\title{
Metode Bercakap-cakap: Pengaruhnya terhadap Keterampilan Berbicara Anak Usia 4-5 Tahun
}

INFORMASI
ARTIKEL

Artikel Histori:

Diterima :

$11 / 06 / 2021$

Direvisi :

20/07/2021

Diterbitkan:

$31 / 07 / 2021$

\section{Keywords: \\ Conversation, \\ Speaking skill, \\ Early Childhood.}

Kata Kunci:

Metode Bercakap-

cakap,

Keterampilan

Berbicara

Anak Usia Dini.

\section{DOI:}

https://doi.org

$\angle 10.46963 / \mathrm{mas}$

h.v4i02.343

Korespondensi

Penulis:

Nur'aini

nuraini@gmail.c

om

\author{
${ }^{1}$ Nur'aini, ${ }^{2}$ Rika Devianti \\ ${ }^{1}$ STAI Auliaurrasyidin, Tembilahan, Riau, Indonesia \\ ${ }^{2}$ STAI Auliaurrasyidin, Tembilahan, Riau, Indonesia
}

ABSTRACT: Language is the ability to communicate with other people. One of the language skills that can be developed first is speaking skill. Speaking skills need to be optimized because they can affect the next child's life. There are various kinds of problems related to speaking skills including some children who have not been able to communicate the ideas in their minds, express their opinions, and have not dared to speak. In addition, the teaching methods used by teachers have an influence on children's interest in expressing their opinions. This study aims to determine the effect of the conversing method on the speaking skills of children aged $4-5$ years. The quantitative approach was carried out using an experimental method of pre-experimental design, one group pretest, and post-test design. Subjects in this study as many as 17 children, data collection techniques using the method of observation and documentation. Furthermore, the data analysis technique used the Wilcoxon Matched Pairs Test formula. The results showed that the method of speaking had an effect on children's speaking skills.

ABSTRAK: Bahasa merupakan kemampuan untuk berkomunikasi dengan orang lain. Salah satu keterampilan berbahasa yang dapat dikembangkan terlebih dahulu adalah keterampilan berbicara. Keterampilan berbicara perlu dioptimalkan karena dapat berpengaruh terhadap kehidupan anak selanjutnya. Terdapat berbagai macam permasalahan terkait keterampilan berbicara diantaranya: Beberapa anak belum mampu mengkomunikasikan ide dalam pikirannya, mengungkapkan pendapatnya, dan belum berani untuk berbicara. Selain itu, metode pengajaran yang digunakan oleh guru memberikan pengaruh terhadap ketertarikan anak untuk mengungkapkan pendapatnya. Penelitian ini bertujuan untuk mengetahui pengaruh metode bercakap-cakap terhadap keterampilan berbicara anak usia 4-5 tahun. Pendekatan kuantitatif dilakukan dengan metode eksperimen desain pre-experimental design jenis one group pretest and post-test design. Subjek dalam penelitian ini sebanyak 17 anak, teknik pengumpulan data menggunakan metode observasi dan dokumentasi. Selanjutnya, teknik analisis data menggunakan rumus Wilcoxon Matched Pairs Test. Hasil penelitian menunjukkan metode bercakap-cakap berpengaruh terhadap keterampilan berbicara anak.

\section{Cara mensitasi artikel:}

Nur'aini, \& Devianti, R. (2021). Metode Bercakap-cakap: Pengaruhnya Terhadap Keterampilan Berbicara Anak Usia 4-5 Tahun. Mitra Ash-Shibyan: Jurnal Pendidikan dan Konseling, 4(02), 135-144. https:// doi.org/10.46963/mash.v4i02.343 


\section{PENDAHULUAN}

Anak usia dini dapat dikatakan sebagai investasi kehidupan di masa yang akan datang. Oleh karena itu, guru dan orang tua sebagai pendidik anak usia dini perlu memperhatikan dan mendorong pertumbuhan dan perkembangan anak agar berkembang secara pesat dan fundamental. Berdasarkan hal tersebut pendidikan bagi anak usia dini dianggap penting dan dapat berpengaruh terhadap kehidupan anak di masa yang akan datang (Sujiono, 2012). Hal tersebut juga sejalan dengan Permendikbud No. 146 Tahun 2014 tentang Kurikulum 2013 PAUD yang menjelaskan bahwa Pendidikan Anak Usia Dini merupakan upaya pembinaan pada anak usia 0-6/8 tahun yang dilakukan melalui pemberian rangsangan pendidikan untuk membantu pertumbuhan dan perkembangan jasmani agar anak memiliki kesiapan dalam memasuki pendidikan lebih lanjut (Depdiknas, 2014).

PAUD berfungsi membina, menumbuhkan dan mengembangkan seluruh potensi anak usia dini secara optimal sehingga terbentuk perilaku dan kemampuan dasar sesuai dengan tahap perkembangannya agar memiliki kesiapan untuk memasuki pendidikan selanjutnya (Trianto, 2013). Tujuan pendidikan anak sejak dini pada dasarnya adalah untuk mengembangkan seluruh aspek perkembangan yang ada pada diri anak. Aspek perkembangan yang perlu dikembangkan terdiri atas enam aspek, diantaranya perkembangan nilai agama dan moral, perkembangan fisik motorik, perkembangan bahasa, perkembangan kognitif, perkembangan sosial emosional dan kemandirian, serta perkembangan seni (Susanto, 2011).

Diantara keenam aspek perkembangan di atas, salah satu bidang pengembangan dalam pertumbuhan kemampuan dasar di Taman Kanakkanak yang menjadi pokok pembahasan adalah pengembangan bahasa. Bahasa merupakan kemampuan untuk berkomunikasi dengan orang lain. Dalam pengertian ini, tercakup semua cara untuk berkomunikasi, dimana pikiran dan perasaan dinyatakan dalam bentuk lambang atau simbol untuk mengungkapkan sesuatu pengertian, seperti dengan menggunakan lisan, tulisan, isyarat, bilangan, lukisan, dan mimik muka (Yusuf, 2009).

Pemahaman tentang perkembangan bahasa, bukan saja dalam bentuk bahasa secara lisan, namun mencakup empat keterampilan berbahasa, diantaranya adalah keterampilan menyimak (mendengarkan), berbicara, membaca, dan menulis /menggambar (Zubaidah, 2003). Salah 
satu keterampilan berbahasa yang dapat dikembangkan terlebih dahulu adalah keterampilan berbicara. Secara umum anak pada usia 4-5 tahun sudah memiliki 1000-2500 kata, sudah mulai bisa bercerita, menyalin huruf-huruf, menulis namanya sendiri, merangkai kata-kata, menguasai 90\% dari fonem dan tata bahasa yang digunakannya, serta mampu berpartisipasi dalam suatu percakapan (Wiyani \& Barnawi, 2014).

Dalam mengembangkan bahasa (berbicara) anak usia dini khususnya anak usia 4-5 tahun, banyak hal yang dapat dilakukan terhadap anak salah satunya adalah penggunaan metode pembelajaran (Eriani \& Dimyati, 2019). Sebagaimana telah dipahami bahwa anak usia dini memiliki karakter yang khas, oleh karena itu metode pembelajaran yang diterapkan hendaknya disesuaikan dengan kekhasan yang dimiliki anak usia 4-5 tahun, sebab metode pembelajaran yang diterapkan akan berpengaruh terhadap keberhasilan proses pengajaran yang dalam hal ini berkaitan dengan keterampilan berbicara anak (Isjoni, 2011).

Melalui kegiatan bercakap-cakap diharapkan akan meningkatkan keberanian anak untuk mengaktualisasikan diri dengan menggunakan kemampuan berbahasa ekspresif, meningkatkan keberanian anak untuk menyatakan secara lisan apa yang harus dilakukan oleh diri sendiri dan anak lain, meningkatkan keberanian anak untuk mengadakan hubungan dengan orang lain, memberi kesempatan kepada anak untuk membangun jati dirinya melalui berdialog, memperluas pengetahuan dan pembendaharaan kata, serta meningkatkan kemampuan bahasa reseptif anak (Wiyani \& Barnawi, 2014).

Berdasarkan observasi awal, diperkuat dengan wawancara, yang dilakukan oleh peneliti, permasalahan yang tampak dalam perkembangan bahasa anak adalah keterampilan berbicara pada anak kelompok usia 4-5 tahun atau kelompok A. Beberapa anak belum mampu mengkomunikasikan ide dalam pikirannya, mengungkapkan pendapatnya, dan belum berani untuk berbicara. Hal tersebut terlihat pada saat guru bertanya ataupun mengajak untuk berbicara, beberapa anak masih belum mampu merespon dengan baik bahkan ada anak yang hanya diam ketika diajak berbicara.

Hal tersebut tentu saja dipengaruhi oleh banyak faktor, baik faktor dalam diri anak maupun dari luar anak. Faktor dari dalam yang mempengaruhi diantaranya berasal dari perkembangan fisik anak, faktor kecerdasan, banyaknya kosakata yang dimiliki anak, dsb. Sedangkan

mitra Ash-Shibynn: Jurnal Pendidikan dan Konseling | Vol. 4, No. 02 (2021) 137 Licensed under CC-BY-SA (c) (1) () 
faktor dari luar meliputi tingkat pendidikan, kebiasaan, dan lingkungan pergaulan. Berkaitan dengan faktor dari luar, kegiatan pembelajaran anak harus menyenangkan dan berpusat pada anak sehingga dapat meningkatkan keterampilan berbicara.

Terdapat berbagai macam metode pembelajaran yang dapat di terapkan di PAUD, namun metode yang dipilih dan diterapkan oleh guru di PAUD As-Shofa Tembilahan Hulu belum mampu menarik minat anak untuk aktif berbicara. Hal ini dikarenakan proses pembelajaran masih didominasi dengan metode ceramah, pembagian tugas, bercerita, bernyanyi, dan bermain. Salah satu metode pembelajaran yang menarik adalah metode bercakap-cakap dikarenakan dalam penggunaan metode bercakap-cakap anak dapat menyatakan gagasan atau pendapat secara verbal. Pengembangan berbicara anak dapat dilakukan dengan metode bercakap-cakap (Khoiriyah \& Rachman, 2019).

Metode bercakap-cakap adalah metode yang mencakup kegiatan di mana seseorang menyampaikan secara lisan kepada orang lain dengan alat bantu atau tanpa alat terkait sesuatu dalam bentuk pesan, informasi atau pun percakapan sederhana yang terdengar menyenangkan (Dhieni, 2007). Kegiatan berbicara bagi anak usia dini berperan dalam membantu perkembangan bahasanya, antara lain dalam meningkatkan ketrampilan berbicara, menambah perbendaharaan kosakata, meningkatkan kemampuan mengucapkan kata-kata, dan melatih merangkai kalimat sesuai dengan tahap perkembangannya (Khoiriyah \& Rachman, 2019)

Oleh karena itu, artikel ini mencoba untuk menggambarkan pengaruh metode bercakap-cakap terhadap keterampilan berbicara anak usia 4-5 tahun di Kelompok A PAUD As-Shofa Tembilahan Hulu.

\section{METODE PENELITIAN}

Penelitian tentang pengaruh metode bercakap cakap terhadap keterampilan berbicara pada kelompok A di PAUD As-Shofa Tembilahan Hulu dilakukan dengan pendekatan kuantitatif. Metode penelitian yang digunakan adalah metode eksperimen dengan desain pre-experimental design dengan jenis one group pretest and post-test design (Arikunto, 2002; Sugiyono, 2016), dengan sampel yang digunakan yaitu 17 anak usia 4-5 tahun. Adapun teknik pengumpulan data yang digunakan dalam penelitian ini yaitu observasi, presentasi lisan/tes lisan, dan dokumentasi. Data kemudian dianalisis menggunakan uji wilcoxon matched pairs test. 


\section{HASIL DAN PEMBAHASAN}

Penelitian ini dilakukan dengan 3 tahapan, yaitu pre-test (sebelum perlakuan), treatment (perlakuan), dan post-test (sesudah perlakuan). Kegiatan pre-test (sebelum perlakuan) dilakukan satu kali pertemuan. Hasil dari kegiatan pre-test ini menunjukkan bahwa kemampuan berbicara anak masih lemah. Hasil penelitian sebelum perlakuan (pre-test) yang diperoleh yaitu skor total hasil pre-test sebesar 67 dengan rata-rata 3,94.

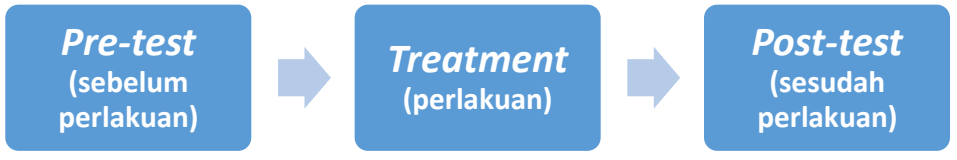

Gambar 1. Tahapan one group pretest and post-test design

Selanjutnya diberikan treatment (perlakuan) menggunakan metode bercakap-cakap. Treatment dilakukan selama enam kali pertemuan. Pada treatment 1, menggunakan metode bercakap-cakap peneliti menyiapkan media (miniatur sekolah) yang disesuaikan dengan tema sebagai topik percakapan, setelah selesai menyiapkan peneliti mengkondisikan anakanak untuk duduk tertib, kemudian anak dikenalkan dengan media yang telah disediakan oleh peneliti.

Setelah dikenalkan media peneliti memberikan kesempatan kepada anak untuk bertanya, setelah peneliti menjawab pertanyaan anakanak peneliti selanjutnya menjelaskan materi saat itu dan merangsang percakapan anak dengan diberikan pertanyaan-pertanyaan yang berkaitan dengan tema, setelah kegiatan percakapan selesai peneliti menyimpulkan materi yang baru saja dibicarakan, dan peneliti mengevaluasi kegiatan percakapan kepada anak secara satu persatu dengan meminta anak menyebutkan kembali apa yang mereka pelajari saat itu.

Prosedur pelaksanaan treatment 2-6 sama halnya dengan treatment 1. Perbedaannya terletak pada media yang digunakan, pada treatment 2 menggunakan media miniatur kandang domba, treatment 3 menggunakan media miniatur kolam ikan, treatment 4 menggunakan media gambar metamorfosis kupu-kupu, treatment 5 menggunakan media origami ayam, dan pada treatment 6 menggunakan media gambar kucing. Pada saat memberikan treatment, peneliti juga meminta bantuan guru kelas dalam menilai bagaimana penerapan metode bercakap-cakap yang dilakukan oleh peneliti apakah sesuai dengan langkah-langkah dari metode

mikra Ash-shibyan: Jurnal Pendidikan dan Konseling | Vol. 4, No. 02 (2021) 139 Licensed under CC-BY-SA (c) (i) () 
bercakap-cakap itu sendiri. Pada saat melakukan penilaian, peneliti juga memberikan lembar observasi penerapan metode bercakap-cakap kepada guru untuk digunakan sebagai pedoman penilaian.

Pada lembar observasi, terdapat tujuh langkah penerapan metode bercakap-cakap dan dari hasil penilaian guru selama enam kali perlakuan, peneliti dianggap baik dalam menerapkan metode bercakap-cakap, dimana peneliti mendapatkan skor 3 pada perlakuan pertama, skor 4 pada perlakuan kedua, skor 5 pada perlakuan ketiga dan keempat, serta skor 6 pada perlakuan kelima dan keenam. Hal tersebut tentu menunjukkan adanya peningkatan dari perlakuan pertama hingga perlakuan terakhir dan hal tersebut dianggap baik bagi guru kelas.

Setelah treatment selesai, selanjutnya dilakukan kegiatan post-test. Kegiatan yang dilakukan sama dengan kegiatan yang dilakukan saat pretest yakni peneliti mengamati anak pada saat pembelajaran dimana pada hari itu seluruh anak diminta untuk bercerita tentang air di depan kelas, peneliti menggunakan pedoman lembar observasi sebagai alat bantu untuk menilai. Hasil penelitian yang diperoleh setelah perlakuan (posttest) menunjukkan bahwa skor total yang diperoleh sebesar 83 dengan rata-rata 4,88 dan hal tersebut meningkat jika dibandingkan dengan hasil pre-test.

Berdasarkan data yang diperoleh dari hasil pre-test dan hasil posttest tentang pengaruh metode bercakap-cakap terhadap keterampilan berbicara pada kelompok A di PAUD As-Shofa Tembilahan Hulu dengan jumlah 17 anak, selanjutnya dianalisis dengan statistik nonparametrik menggunakan uji jenjang bertanda Wilcoxon (Wilcoxon Matched Pairs Test). Alasan menggunakan rumus wilcoxon matched pairs test yaitu untuk mencari perbedaan dalam hal kemampuan berbicara sebelum dan sesudah diberikan perlakuan menggunakan metode bercakap-cakap. Dalam uji Wilcoxon, besar selisih angka antara positif dan negatif diperhitungkan karena sampel yang digunakan dalam penelitian ini kurang dari 30 anak yaitu sebanyak 17 anak maka tes uji wilcoxon menggunakan tabel penolong. 
Tabel 1. Hasil uji Wilcoxon dengan bantuan tabel penolong

\begin{tabular}{|c|c|c|c|c|c|c|}
\hline \multirow{2}{*}{$\begin{array}{l}\text { Nama } \\
\text { Anak }\end{array}$} & \multirow{2}{*}{$\begin{array}{c}\text { Pre-Test } \\
(\mathrm{X})\end{array}$} & \multirow{2}{*}{$\begin{array}{c}\text { Post-Test } \\
(Y)\end{array}$} & \multirow{2}{*}{$\begin{array}{l}\text { Beda } \\
(X-Y)\end{array}$} & \multirow{2}{*}{$\begin{array}{l}\text { Rank } \\
(\mathrm{X}-\mathrm{Y})\end{array}$} & \multicolumn{2}{|c|}{ Tanda Rank } \\
\hline & & & & & + & - \\
\hline PT & 5 & 6 & +1 & 3.5 & +3.5 & 0 \\
\hline AR & 3 & 5 & +2 & 9 & +9 & 0 \\
\hline $\mathrm{AZ}$ & 3 & 5 & +2 & 9 & +9 & 0 \\
\hline FH & 1 & 2 & +1 & 3.5 & +3.5 & 0 \\
\hline $\mathrm{YZ}$ & 4 & 5 & +1 & 3.5 & +3.5 & 0 \\
\hline $\mathrm{AD}$ & 6 & 6 & 0 & 0 & 0 & 0 \\
\hline NR & 6 & 6 & 0 & 0 & 0 & 0 \\
\hline$A B$ & 6 & 6 & 0 & 0 & 0 & 0 \\
\hline $\mathrm{KY}$ & 3 & 5 & +2 & 9 & +9 & 0 \\
\hline NS & 4 & 6 & +2 & 9 & +9 & 0 \\
\hline AN & 3 & 4 & +1 & 3.5 & +3.5 & 0 \\
\hline $\mathrm{ZH}$ & 4 & 5 & +1 & 3.5 & +3.5 & 0 \\
\hline PA & 4 & 6 & +2 & 9 & +9 & 0 \\
\hline RS & 3 & 3 & 0 & 0 & 0 & 0 \\
\hline BT & 3 & 3 & 0 & 0 & 0 & 0 \\
\hline $\mathrm{RQ}$ & 3 & 4 & +1 & 3.5 & +3.5 & 0 \\
\hline NF & 6 & 6 & 0 & 0 & 0 & 0 \\
\hline \multicolumn{5}{|c|}{ JUMLAH } & $T+=66$ & $\mathrm{~T}-=0$ \\
\hline
\end{tabular}

Berdasarkan tabel hasil penelitian dengan menggunakan rumus penolong Wilcoxon, diketahui bahwa nilai $\mathrm{T}_{\text {hitung }}$ yang diperoleh yaitu 0 , karena jumlah tanda jenjang terkecil (positif dan negatif) dinyatakan sebagai nilai $\mathrm{T}_{\text {hitung. }}$ Thitung diperoleh dari hasil perbandingan dari beda hasil kegiatan pre-test dan kegiatan post-test. Lalu diberi peringkat dimulai dari angka paling kecil diberi peringkat satu dan seterusnya hingga paling besar. Setelah memperoleh nilai dari $\mathrm{T}_{\text {hitung }}$ kemudian $\mathrm{T}_{\text {hitung }}$ dibandingkan dengan $\mathrm{T}_{\text {tabel. }} \mathrm{T}_{\text {tabel }}$ merupakan nilai dari tabel kritis dalam uji jenjang Wilcoxon. Dalam penelitian ini subjek penelitian berjumlah 17 anak, maka $\mathrm{N}=17$. Maka, untuk mendapatkan nilai $\mathrm{T}_{\text {tabel, }}$ dapat dilihat pada tabel kritis dalam uji jenjang Wilcoxon dengan melihat taraf signifikan sebesar 5\% dan $N=17$. Sehingga diperoleh nilai $T_{\text {tabel }}$ sebesar 34 berarti $T_{\text {hitung }} \leq T_{\text {tabel }}(0$ s 34). Hal ini menunjukkan bahwa nilai $\mathrm{T}_{\text {tabel }}$ lebih besar dibanding dengan $\mathrm{T}_{\text {hitung, }}$ maka pengambilan keputusannya yaitu Ho ditolak dan Ha diterima. Dengan demikian, berdasarkan hasil temuan penelitian yang diperkuat oleh teori maka dapat disimpulkan bahwa terdapat pengaruh metode bercakap-cakap terhadap keterampilan berbicara pada kelompok A di PAUD As-Shofa Tembilahan Hulu.

mitra Ash-shibyan: Jurnal Pendidikan dan Konseling | Vol. 4, No. 02 (2021) 141 
Tabel 2. Perbandingan hasil pretest dan posttest

\begin{tabular}{|c|c|c|c|c|}
\hline No. & Pre-test & Post-test & $\begin{array}{c}\text { Beda } \\
\text { (D) }\end{array}$ & $\begin{array}{l}\text { Beda } \\
(\mathrm{D})^{2}\end{array}$ \\
\hline 1. & 5 & 6 & +1 & 1 \\
\hline 2. & 3 & 5 & +2 & 4 \\
\hline 3. & 3 & 5 & +2 & 4 \\
\hline 4. & 1 & 2 & +1 & 1 \\
\hline 5. & 4 & 5 & +1 & 1 \\
\hline 6. & 6 & 6 & 0 & 0 \\
\hline 7. & 6 & 6 & 0 & 0 \\
\hline 8. & 6 & 6 & 0 & 0 \\
\hline 9. & 3 & 5 & +2 & 4 \\
\hline 10. & 4 & 6 & +2 & 4 \\
\hline 11. & 3 & 4 & +1 & 1 \\
\hline 12. & 4 & 5 & +1 & 1 \\
\hline 13. & 4 & 6 & +2 & 4 \\
\hline 14. & 3 & 3 & 0 & 0 \\
\hline 15. & 3 & 3 & 0 & 0 \\
\hline 16. & 3 & 4 & +1 & 1 \\
\hline 17. & 6 & 6 & 0 & 0 \\
\hline \multicolumn{3}{|c|}{$\Sigma$} & 16 & 26 \\
\hline
\end{tabular}

$$
t^{1}=\frac{\Sigma D+n}{\Sigma D^{2}-\left\{\frac{(D)^{2}+n}{n(n-1)}\right\}}
$$$$
t=\frac{16+17}{26-\left\{\frac{(16)^{2}+17}{17(17-1)}\right\}}
$$$$
t=\frac{0,94}{26-\left\{\frac{15,06}{272}\right\}}
$$$$
t=\frac{0,94}{25,945}
$$$$
t=0,036=3,6 \%
$$

Setelah didapatkan bahwa metode bercakap-cakap berpengaruh terhadap keterampilan berbicara pada kelompok A, selanjutnya untuk mencari seberapa besar pengaruh metode bercakap-cakap dilakukan analisis data menggunakan rumus uji t. Dan didapatkan hasil yaitu 3,6\%. Dengan demikian, dapat dikatakan bahwa metode bercakap-cakap berpengaruh terhadap keterampilan berbicara pada kelompok A di PAUD As-Shofa Tembilahan Hulu yaitu sebesar 3,6\%. Metode bercakap-cakap tidak hanya berpengaruh terhadap keterampilan berbicara hal ini diperkuat dengan hasil penelitian yang menunjukkan bahwa metode bercakap-cakap berpengaruh terhadap kemampuan berbahasa lisan, kemampuan membaca anak, kemampuan memperoleh kosa kata, serta meningkatkan kemampuan nilai-nilai moral (Astuti, 2012; Utari, 2014; Komariah et al., 2019; Ayuandia et al., 2017). Karena itu metode bercakapcakap dapat digunakan untuk meningkatkan berbagai aspek perkembangan anak usia dini.

\section{SIMPULAN}

Berdasarkan hasil penelitian dan analisis data maka dapat disimpulkan bahwa penerapan metode bercakap-cakap yang dilakukan 
peneliti dianggap baik. Hal tersebut ditunjukkan oleh peningkatan dari perlakuan pertama hingga perlakuan terakhir. Selanjutnya terdapat pengaruh penerapan metode bercakap-cakap terhadap keterampilan berbicara. Hal tersebut dapat diketahui dari peningkatan hasil pre-test dan post-test yang dilakukan. Baik dalam hal menjawab pertanyaan sederhana, terutama yang menggunakan kata tanya apa, mengapa, di mana, berapa, dan bagaimana, maupun bagaimana anak mengungkapkan pendapatnya secara sederhana, dan merangkai kata menjadi kalimat sederhana yang bermakna. Dengan demikian, dapat dikatakan bahwa metode bercakap-cakap berpengaruh terhadap keterampilan berbicara pada usia 4-5 tahun. Agar metode bercakap-cakap lebih optimal menstimulasi kemampuan bahasa anak guru harus menyesuaikan dengan kemampuan anak pada kelas tersebut, materi percakapan atau kata-kata yang dipilih dalam bercakap-cakap hendaknya disesuaikan dengan capaian perkembangan bahasa anak. Berbagai permasalahan terkait perkembangan bahasa anak usia dini dapat distimulasi dengan berbagai metode pembelajaran lainnya, karena itu penting untuk guru dapat memahami dan menerapkan sesuai dengan kebutuhan dan tujuan pembelajaran.

\section{DAFTAR PUSTAKA}

Arikunto, S. (2002). Prosedur Penelitian Suatu Pendekatan Praktik. Jakarta: Rineka Cipta.

Astuti, H. (2012). Meningkatkan Kemampuan Berbahasa Lisan Anak Melalui Metode Bercakap-Cakap Bagi Anak Kelompok B TK Pertiwi Nangsri Manisrenggo Klaten Tahun Ajaran 2012/2013, (Skripsi Universitas Muhammadiyah Surakarta.).

Ayuandia, N., Saparahayuningsih, S., \& Ardina, M. (2017). Meningkatkan Keterampilan Berbicara Melalui Metode Karyawisata pada Anak Kelompok B Lab School PAUD UNIB Kota Bengkulu. Jurnal Potensia PGPAUD UNIB, 2(1), 32-36.

Depdiknas. (2014). Permendikbud No. 146 Tahun 2014. Jakarta: Depdiknas.

Dhieni, N. (2007). Penggunaan Metode Bercakap-Cakap dan Keterampilan Berbicara Anak Usia Dini. Jakarta: Universitas Terbuka.

Eriani, E., \& Dimyati. (2019). Story Telling using Madihin : Learning Methods for Early Childhood Listening Skills. Jurnal Obsesi : Jurnal Pendidikan Anak Usia Dini, 3(2), 303-310. https:// doi.org/10.31004/obsesi.v3i2.172

Isjoni. (2011). Model Pembelajaran Anak Usia Dini. Bandung: Alfabeta.

Khoiriyah, \& Rachman, A. U. (2019). Metode Bercakap-cakap Sebagai Kemampuan Peningkatan Berbicara Anak. Journal of Early Childhood 
Care \& Education $\quad$ (JECCE), $\quad 2(1), \quad 38-54$. https://doi.org/10.26555/jecce.v2i1.567

Komariah, N., Haenilah, E. Y., \& Riswandi, R. (2019). Penggunaan Metode Bercakap-Cakap dan Keterampilan Berbicara Anak Usia Dini. Jurnal Pendidikan Anak (PG-PAUD FKIP Universitas Lampung), 5(1).

Sugiyono. (2016). Metode Penelitian Pendidikan. Bandung: Alfabeta.

Sujiono, Y. N. (2012). Konsep Dasar Pendidikan Anak Usia Dini. Jakarta: Indeks.

Susanto, A. (2011). Perkembangan Anak Usia Dini (Pengantar dalam Berbagai Aspeknya). Jakarta: Kencana.

Trianto. (2013). Desain Pengembangan Pembelajaran Tematik bagi Anak Usia dini TK/RA dan Anak Usia Kelas Awal SD/MI. Jakarta: Kencana Prenada Media Guru.

Utari, R. (2014). Pengaruh Metode Bercakap-Cakap Terhadap Kemampuan Membaca Anak Usia 5-6 Tahun di TK Pelangi Medan T.A 2013/2014., (Undergraduate Thesis, UNIMED).

Wiyani, N. A., \& Barnawi. (2014). Format PAUD (Konsep, Karakteristik, dan Implementasi Pendidikan Anak Usia Dini. Yogyakarta: Ar-Ruzz Media.

Yusuf, S. (2009). Psikologi Perkembangan Anak dan Remaja. Bandung: Rosdakarya.

Zubaidah, E. (2003). Pengembangan Bahasa Anak Usia Dini. Yogyakarta: Universitas Negeri Yogyakarta. 